\title{
PELAKSANAAN PROSEDUR PELAYANAN PEMBUATAN AKTA KELAHIRAN
}

\author{
A.M. Yadisar \\ Fakultas Ilmu Sosial dan Ilmu Politik Universitas Kapuas \\ Email: yadisara@yahoo.co.id
}

\begin{abstract}
Abstak: Penyelenggaraan administrasi kependudukan terutama dalam pencatatan kelahiran yang dilaksanakan selama ini sudah berjalan sesuai harapan yang mana system prosedurnya sudah dapat dilakukan baik secara manual maupun online, mengingat manajemen pendaftaran, pencatatan dan pengendalian penduduk serta pengelolaan datanya sudah dilakukan secara baik dan tertib, sehingga mengakibatkan pertumbuhan penduduk menjadi terkendali serta pemanfaatan data penduduk bagi kepentingan pembangunan menjadi maksimal maksimal. perlunya mengkonstruksi perumusan kebijakan pelayanan pembuatan Akta Kelahiran dengan suatu regulasi yang tanggap pada norma-norma lokal yang berlaku dan berkembang dalam masyarakat setempat. Perlu dilakukan sosialisasi kepada masyarakat secara berkesinambungan tentang tata cara pembuatan Akta Kelahiran, baik mengenai prosedur, biaya, waktu, dan kegunaannya
\end{abstract}

Kata Kunci : Pelaksanaan, Prosedur, Pelayanan, Akta Kelahiran

Dunia tengah menuju era global village di mana batas-batas antarwilayah dan negara akan menjadi kabur. Daya saing suatu negara beserta institusiinstitusi didalamnya merupakan kunci keunggulan pada saat globalisasi terwujud. Keunggulan dalam arti mampu bersaing dikarenakan mempunyai sesuatu yang .unik, dan berbeda. dalam beradaptasi dengan keinginan masyarakat global. Dinamika internal institusi pemerintah sangat dibutuhkan untuk dapat selalu menyesuaikan dengan dinamika keinginan masyarakat global. Peningkatan kinerja yang tergambar dalam kualitas pelayanan yang prima, akuntabel, transparan menjadi sesuatu yang harus dilakukan. Pelayanan publik yang prima terhadap masyarakat global tanpa diskriminasi menjadi tanggung jawab organisasi publik. Model desentralisasi harus diutamakan dalam peningkatan kualitas pelayanan publik

Negara pada hakikatnya berkewajiban untuk memberikan Perlindungan dan pengakuan terhadap penentuan status pribadi dan status hukum setiap peristiwa kependudukan dan peristiwa penting yang dialami oleh penduduk yangberada di dalam danlatardr luar wilayah Negara Kesatuan Republik Indonesia. Dengan demikian kewajiban Pemerintah adalah memberikan perlindungan dan pengakuan terhadap: penentuan status-pribadi, penentuan status-hukum atas, peristiwa- kependudukan dan peristiwa-penting yang dialami penduduk.

Pemberian perlindungan, pengakuan dan penentuan status pribadi dan status hukum atas setiap peristiwa kependudukan dan persitiwa penting yang dialami penduduk itu, perlu pengattran. Sehingga diterbitkanlah UndangUndang Nomor 24 Tahun 2013 Tentang Administrasi Kependudukan. Pengaturan administrasi kependudukan hanya dapat dilaksanakan apa bila didukung oleh pelayanan yang optimal dan peningkatan kesadaran penduduk Administrasi kependudukan sebagai suatu sistem diharapkan dapat diselenggarakan sebagai bagian dari penyelenggaraan administrasi negara. Dari sisi kepentingan pendudulq administrasi kependudukan memberikan pemenuhan hak-hak administatif, seperti pelayanan publik serta perlindungan yang berkenaan dengan dokumen kependudukan, tanpa adanya perlakuan yang diskriminatif.

Perkembangan penduduk yang cukup pesat merupakan satu fenomena yang menjadi perhatian serius Pemerintah Pusat maupun Pemerintatr Daerah, permasalahan yang paling esensial adalah yang berkaitan dengan penyediaan lapangan kerja /usaha serta penyediaan bahan pangan. Faktor yang sangat umum yang mempenganrhi 
pertumbutran penduduk di suatu daerah antara lain adalah angka kelahiran, angka kematian, dan angka migrasi (migrasi datang dan migrasi masuk). Kejadian ini biasa disebut dengan kejadian vital penduduk

Para pemakai data penduduk, khususnya para perencana, pengambil kebijaksanaan dan peneliti sangat membutuhkan data penduduk yang berkesinambungan dari tahun ke tahun. Sementara sumber datayang menghasilkan data penduduk yang dapat dipakai dan dipercaya hanya menyediakan secara periodik lima tahrran, yaitu seirsus penduduk pada tahun-tahun yang berakhiran angka nol dan survei penduduk antar sensus pada pertengahan dua sensus berurutan. Walaupun ada sumber data kependudukan yang lain yaitu registrasi penduduk, tetapi cakupan pencatatannya masih belum bagus sehingga angka ini belum dapat digunakan unfuk perencanaan pembangunan. Sehingga untuk mengetatrui keadaan jumlah penduduk di luar tatrun sensus dibuatlah angka proyeksi atau estimasi penduduk.

Fasilitasi urusan-urusan yang menyangkut kepentingan publik dan pelayanan publik tentunya sudah menjadi tanggung jawab pemerintah melalui aparatur-aparaturnya maupun unit-unit kerja yang telah diserahi bidang tugas sesuai dengan tugas pokok dan fingsi masing-masing, termasuk dalam hal ini adalah Dinas Kependudukan dan Pencatatan Sipil Kabupaten Sintang. Dinas Kependudukan dan Pencatatan Sipil Kabupaten Sintang mempunyai tugas melaksanakan sebagian kewenangan Kabupaten.

Dalam menjalankan tugas-tugas pelayanan tersebut, Dinas Kependudukan dan Pencatatan Sipil Kabupaten Sintang dihadapkan pada berbagai persoalan yang berhubungan dengan kondisi riil yang terdapat baik pada organisasi dinas maupun pada masyarakat. Kondisi-kondisi tersebut antara lain: tuntutan masyarakat yang ingin dilayani secara cepat serta lengtcap, sarana dan prasarana yang minim, pemerintah desa yang belum berjalan sebagaimana mestinya, aparatur yang belum memadai, dan sebagainya. Sehubungan dengan itu, penulis merasa tertarik untuk melakukan penelitian mengenai Pelayanan Akta Kelahiran di Dinas Kependudukan dan Pencatatan Sipil Kabupaten Sintang

Kualitas pelayanan publik telah lama menjadi kajian di banyak negara. Tuntutan masyarakat terhadap pelayanan yang berkualitas hampir setiap hari dapat dibaca di media cetak atau dilihatdi media elektronik, juga digunjingkan oleh banyak orang di rumah maupun di tempat umum. Sudah bukan rahasia lagi bahwa sebagian organisasi publik masih harus meningkatkan pelayanan yang diberikannya kepada masyarakat (Warella, 1997:14). Beberapa sarjana lain dalam bidang administrasi publik juga menyarankan betapa pentingnya fungsi pelayanan, baik secara implisit maupun eksplisit. Dwight Waldo (Kencana, 1999:26) menyebutkan bahwa administrasi publik adalah manajemen dan organisasi daripada manusia-manusia dan peralatannya guna mencapai tujuan pemerintah. Di samping itu Hardijanto (2000:1) juga menyebutkan adanya tuntutan masyarakat kepada pemerintah untuk dapat meningkatkan pemberdayaan masyarakat dan mengutama kan pelayanan primakepada masyarakat tanpa diskriminasi.

Pembahasan mengenai kualitas pelayanan dalam penelitian ini banyak mendasarkan pada teoriteori manajemen pemasaran (marketing science). Hal itu sejalan dengan semangat wirausaha dalam birokrasi, yang merubah paradigm pelayanan publik menjadi lebih berorientasi kepada kebutuhan publik sebagai pelanggan dan bukan kebutuhan birokrat. Pengukuran-pengukuran kualitas pelayanan dan kepuasan pelanggan yang diperoleh melalui survei konsumen telah menjadi barometer yang banyak digunakan terhadap kinerja bisnis selama beberapa puluh tahun terakhir (Hurley \& Hoofman, 1998: 211). Menurut Parasuraman, Zeithaml, dan Berry (1988: 14), kualitas jasa (service quality) ditentukan oleh lima faktor, yaitu: (1) penampilan (tangibles); (2) kehandalan (reliability); (3) daya tanggap (respon-siveness); (4) jaminan (assurance); dan (5) kepedulian (empathy). Kelima factor tersebut juga telah diuji oleh Cronin \& Taylor (1992: 66, 1994: 127). 
Pentingnya kualitas pelayanan dalam bidang jasa saat ini juga dirasakan pada sektor pelayanan publik. Kesadaran publik akan hakhaknya pada saat ini telah meningkat, sehingga publik tidak menyukai kebijakan negatif seperti hukuman misalnya. Sebaliknya publik menginginkan kualitas pelayanan yang prima. Untuk mengantisipasi kondisi ini, Osborne (1992) menyarankan agar dilakukan transformasi semangat kewirausahaan ke dalam birokrasi, dimana salah satunya menyangkut bidang kualitas jasa yaitu prinsip pemerintahan yang berorientasi pelanggan, memenuhi kebutuhan pelanggan, dan bukan birokrasi.

Menurut Irawan (2002:18-19) pada dasarnya ada dua hal fundamental yang harus disadari setiap perusahaan dalam memformulasikan kepuasan pelanggan Pertama, adalah strategi kepuasan pelanggan haruslah mulai dengan harapan pelanggan. Secara sederhana, kepuasan akan terjadi kalau perusahaan mampu menyediakan produk, pelayanan, harga, dan aspek lain sesuai dengan atau melebihi harapan pelanggan. Kedua, strategi mewujudkan kepuasan pelanggan haruslah dimulai dengan memilih pelanggan yang benar.

Kesalahan dalam memilih pelanggan dapat mengakibatkan perusahaan yang sudah matimatian melakukan perbaikan produk atau pelayanan, namun kinerja keuangannya tidak juga membaik, ternyata problemnya adalah pemilihan pelanggan yang tidak tepat, karena salah strategi segmentasi dan targeting. Strategi kepuasan pelanggan pada dasarnya tidak bisa dilepaskan dengan strategi segmentasi. Bukan produk atau pelayanan yang diperbaiki tetapi pekerjaan pertama adalah pemilihan pelanggan yang akan diperbaiki tingkat kepuasannya lebih dahulu Penyelenggaraan pelayanan publik seringkali menghadapi hambatan dalam memformulasikan strategi segmentasi. Pertama, karena mental atau anggapan sebagai pelayan umum yang dituntut untuk memberikan kualitas pelayanan yang sama untuk seluruh segmen yang ada dalam masyarakat, walaupun sebenarnya mereka mempunyai harapan yang berbeda. Masyarakat berpenghasilan tinggi tentu mempunyai tuntutan yang berbeda dengan masyarakat berpenghasilan menengah, tuntutan masyarakat berpenghasilan menengah tentu berbeda dengan masyarakat berpenghasilan rendah. Demikian pula jika dilihat dari sisi pendidikan dan domisili geografis yang menyebabkan tuntutan kualitas pelayanan yang beragam pula. Kedua, karena penyelenggaraan pelayanan publik pada umumnya bersifat monopoli, maka keinginan untuk menjadi lembaga pelayanan yang berfokus kepada pencapaian kepuasan pelanggan relatif lemah.

Dalam rangka melayani masyarakat, Dinas Kependudukan'dan Pencatatan Sipil Kabupaten Sintang dibekali standar prosedur kerja pelayanan pembuatan Akta Kelahiran sebagaimana PERMENDAGRI Nomor 9 tahun 2016 tentang Percepatan Peningkatan Cakupan Akta Kelahiran. Sebagai lembaga pelayanan masyarakat manajemen Dinas Kependudukan'dan Pencatatan Sipil Kabupaten Sintang Dinas Kependudukan'dan Pencatatan Sipil Kabupaten Sintang juga mengacu kepada Keputusan Menpan Nomor 81 Tahun 1993, yang menyebutkan bahwa suatu pelayanan umum harus memperhatikan delapan dimensi: (1) kesederhanaan; (2) kejelasan dan kepastian; (3) keamanan; (4) keterbukaan; (5) efesien; (6) ekonomis; (7) keadilan yang merata; dan (8) ketepatan waktu.

Menurut Marzuki Usman (Warella, 1997: 15) dewasa ini konsep kualitas telah menjadi suatu kredo universal dan telah menjadi faktor yang sangat dominan terhadap keberhasilan suatu organisasi. Quliaty mindset ini tidak saja dihadapi lembaga penyelenggara jasa-jasa komersial, tetapi telah menembus lembagalembaga pemerintahan yang selama ini resisten terhadap tuntutan kualitas pelayanan publik yang prima.

Standar pelayanan yang ditetapkan rnenurut SANKRI (dalam Ridwan, 2003 :14) mempunyai tujuan: "(a).menjadi alat monitoring dan analisis terhadap kinerja pelayanan sesuai dengan sasaran yang telah ditetapkan; (b). menjadi alat komunikasi yamg efektif anatara masyarakat pelanggan dengan penyedia langganan; (c). memberikan fokus yang jelas; (d). memberikan informasi 
mengenai akuntabititas pelayanan yang harus dipertanggung jawabkan oleh penyedia layanan; dan (e). menjadi alat bagi pengambilan keputusan. Berdasarkan hasil survey yang dilakukan UGM (dalam Sudrajat, 2006), menjelaskan bahwa secara umum stakeholder menilai bahwa kualitas pelayanan publik mengalami perbaikan setelah diberlakukan otonomi daerah; namun dilihat dari sisi efisiensi dan efektifitas, responsivitas, kesamaan perlakuan masih jauh dari yang diharapkan dan masih memiliki berbagai kelemahan.

Secara tegas Kaufman (dalam Supriyatna 1996:90) menyatakan bahwa: Tugas birokrasi pemerintah adalah melayani (service) dan mengatur (regulasi) masyarakat. Tugas pelayanan lebih menekankan kepada mendahulukan kepentingan umum, mempermudah urusan publik, mempersingkat waktu proses pelaksanaan urusan publik dan memberikan kepuasan kepada publik. Sedangkan tugas mengatur lebih menekankan kepada kekuasaan atau power yang melekat pada posisi jabatan birokrasi.

Tugas pelayanan publik merupakan tugas yang berat disandang oleh pemerintah. Oleh karena itu diperlukan adarrya manajemen pelayanan publik/masyarakat. Dalam kehidupan masyarakat yarrg kompleks, terdapat berbagai kebutuhan yang kompleks juga sehingga menuntut pelayanan pemerintah yang baik dan berkualitas. Pada kondisi inilatr sebenarnya pemerintah mengelami dilema dalam pemberian pelayanan publik yang berkualitas. Sebab masalah dan kebutuhan masyarakat yang dihadapi beraneka rugam. Selain itu tingkat kepuasan masyarakat yang dilayani juga berbeda-beda sehingga selalu ada yang tidak merasa puas dalam pelayanan. Sementara itu, disaat bersamaan pemerintah mengalami banyak keterbatasan, baik dari segi pendanaan, kelembagaan,personil atau keahlian.

Pelayanan publik yang mendapat banyak sorotan dalam beberapa tahun terakhir ini adalah pelayanan di bidang kependudukan dan catatan sipil yang semakin meningkat. Sejalan dengan perkembangan dan perubahan jumlah penduduk yang semakin meningkat menyebabkan tuntutan pelayanan publik di bidang kependudukan dan catatan sipil yang lebih baik sangat diharapkan.

\section{METODE PENELITIAN}

Penelitian terhadap kualitas prosedur pelayanan Pembuatan Akta Kelahiran di Dinas Kependudukan Pencatatan Sipil Kabupaten Sintang menggunakan pendekatan penelitian deskriptif kualitatif yang bersifat menerangkan fenomena yang diteliti. Data dalam penelitian ini terdiri : 1) data primer, yaitu data yang diperoleh dari hasil wawancara dengan informan. 2) data sekunder, yaitu data yang diperoleh dari dokumen, laporan dan buku-buku yang mendukung data. Sementara instrumen penelitian adalah peneliti sendiri, dengan dilengkapi panduan wawancara kepada key person untuk memperoleh data yang diperlukan.

Informan yang dipilih dalam penelitian ini adalah a) Pejabat dari Dinas Kependudukan dan Pencatatan Sipil Kabupaten Sintang, b) Pegawai dari Dinas Kependudukan dan Pencatatan Sipil Kabupaten Sintang, c) Masyarakat pengguna pelayanan yang ditemui secara accidental di lapangan. Pengumpulan data yang dipergunakan dalam rangka penelitian adalah sebagai berikut : 1) Wawancara mendalam, yaitu melakukan wawancara kepada informan yang terlibat langsung dan mengetahui pelaksanaan kebijakan pembuatan Akta Kelahiran tersebut, 2) Pengamatan langsung, yaitu peneliti terjun langsung ke lapangan dan mengamati secara langsung pelaksanaan kebijakan pembuatan Akta Kelahiran dimaksud. Analisis data yang digunakan adalah analisis taksonomis yaitu bentuk analisis yang lebih rinci dan mendalam dalam membahas suatu tema atau pokok permasalahan. Dimana domaian atau bidang yang ditonjolkan perlu dilacak secara mendalam dan terinci struktur internalnya.

\section{HASIL DAN PEMBAHASAN Prosedur Pelayanan}

Pelayanan di bidang kependudukan dan catatan sipil yang semakin meningkat. Sejalan dengan perkembangan dan perubahan jumlah penduduk 
yang semakin meningkat menyebabkan tuntutan pelayanan publik di bidang kependudukan dan catatan sipil semakin meningkat. Undang-Undang Nomor 24 Tahun 2013 tentang Administrasi Kependudukan menegaskan penyelenggaraan administrasi kependudukan bertujuan untuk: 1)Memberikan keabsahan identitas dan kepastian hukum atas dokumen penduduk untuk setiap peristiwa kependudukan dan peristiwa penting yang dialami oleh penduduk; 2) Memberikan perlindungan status hak sipil penduduk; 3) Menyediakan data dan informasi kependudukan secara nasional mengenai pendafraran penduduk dan pencatatan sipil pada berbagai tingkatan secara akurat, lengkap, mutakhir, dan mudah diakses sehingga menjadi acuan bagi perumusan kebijakan dan pembangunan pada umumnya; 4) Mewujudkan tertib administrasi kependudukan secara nasional danterpadu; dan 5) Menyediakan data penduduk yang menjadi rujukan dasar bagi se ktorterkait dalam penyelenggaraan setiap kegiatan pemerintahan, pembangunan, dan kemasyarakatan. Peristiwa Kependudukan antara lain Perubahan Alamat, Pindah Datang untuk menetap, Tinggal Terbatas, serta Perubahan Status Orang Asing Tinggal Terbatas menjadi Tinggal Tetap dan Peristiwa Penting, antara lain Kelahiran, Lahir Mati, Kematian, Perkawinan, dan Perceraian, termasuk Pengangkatan, Pengakuan dan Pengesahan Anak, serta Perubahan Status Kewarganegaraan, Ganti Nama dan Peristiwa Penting lainnya yang dialami oleh seseorang merupakan Kejadian yang harus dilaporkan karena membawa Implikasi Perubahan Data Identitas atau Surat Keterangan Kependudukan. Untuk itu setiap Peristiwa Kependudukan dan Peristiwa Penting memerlukan Bukti yang Sah untuk dilakukan Pengadministrasian dan Pencatatan sesuai dengan Ketentuan UndangUndang.

Akta Kelahiran merupakan salah satu aspek penting dalam Sistem Administrasi Kependudukan. Berdasarkan Peraturan Menteri Dalarn Negeri Nomor 28 Tahun 2005 Tentang Pedoman Penyelenggaraan Pendaftaran Penduduk Dan Pencatatan Sipil Di Daerah dinyatakan Peristiwa Penting adalah Kejadian yang dialami oleh seseorang meliputi : Kelahiran, Lahif Mati, Kematian, Perkawinan, Perceraian, Pembatalan Perkawinan, Pengangkatan, Pengakuan dan Pengesahan Anak Perubahan Nama, Perubahan Kewarganegaraan dan Peristiwa Penting lainnya. Dalam uapaya percepatan pembuatan Akta Kelahiran Kementrian Dalam Negeri mengeluarkan Peraturan Menteri Dalam Negeri Nomor: 9 Tahun 2016 tentang Percepatan Peningkatan Cakupan Kepemilikan Akta Kelahiran.

Akta kelahiran adalah data outentik yang dipetik sebagian dari register akta kelahiran, yang diterbitkan oleh pejabat yang berwenang berdasarkan peraturan perundangan. Mamfaat Akta Kelahiran bagi setiap orang yaitu: Identitas anak; Administrasi kependudukan (KTP,KK); Untuk keperluan sekolah; Untuk mendaftarkan pernikahan di KUA; Mendaftar pekerjaan; Persyaratan pembuatan paspor; Untuk mengurus hak ahli waris; Mengurus Ansuransi; Mengurus Tunjangan Keluarga; Mengurus hak pensiun; dan Untuk melaksanakan ibadah haji. Prosedur pengurusan pembuatan Akta Kelahiran dapat dilakukan dengan cara manual maupun dengan cara online.

Prosedur pembuatan Akta Kelahiran secara manual dapat dilakukan di Dinas Kependudukan dan Pencatatan Sipil Kabupaten Sintang dengan cara: 1) Pemohon mengisi dan menandatangani surat keterangan kelahiran dan menyerahkan persyaratan; 2) Petugas melakukan verifikasi dan validasi terhadap persyaratan dan serta merekam data kelahiran dalam database kependudukan; 3) Pejabat pencatatan sipil pada intansi pelaksana menandatangani dan menerbitkan register Akta Kelahiran dan kitipan Akta Kelahiran; 4) Kutipan Akta Kelahiran diberikan kepada pemohon. Persyaratan yang harus dilengkapi oleh pemohon pada saat pengurusan pembuatan Akta Kelahiran yaitu: a) Surat keterangan lahir dari dokter/bidan/ penolong kelahiran; b) Akta nikah/kutipan akta perkawinan; c) Kartu Keluarga dimana penduduk akan didaftarkan sebagai anggota keluarga; d) KTP Elektronik orang tua/wali/pelapor; e) Paspor 
bagi WNI bukan penduduk dan orang asing. Bagi kelahiran anak yang tidak diketahui asal usulnya atau keberadaan orang tuanya dapat dilakukan dengan cara yaitu: 1) Melampirkan berita acara pemeriksaan (BAP) dari kepolisian; 2) Menggunakan Surat Pernyataan Tanggung Jawab Mutlak (SPTJM) kebenaran data kelahiran yang ditandatangani oleh wali/penanggungjawab.

Sedangkan prosedur pembuatan Akta Kelahiran dengan cara online dilakukan dengan cara yaitu: 1) Pemohon melakukan register pada http:// www.dukcapil.kemendagri.go.id/layananonline untuk mendapatkan hak akses sebagai pengguna aplikasi pencatatan kelahiran; 2) Pemohon yang sudah mendapatkan hak akses, mengisi formulir pada aplikasi pencatatan kelahiran dan mengunggah persyaratan yaitu: a) Surat keterangan lahir dari dokter/bidan/penolong kelahiran, b) Akta nikah/kutipan akta perkawinan, c) Paspor bagi WNI bukan penduduk dan orang asing; 3) pemohon yang telah mengisi formulir aplikasi pencatatan kelahiran dan melengkapi persyaratan akan mendapatkan tanda bukti permohonan; 4) Petugas pada intansi pelaksana melakukan verifikasi dan validasi data permohonan dengan basis data/biodata yang tersimpan dalam SIAK; 5) Setelah dilakukan verifikasi dan validasi data, pejabat pencatatan sipil pada intansi pelaksana menandatangani dan menerbitkan register akta kelahiran; 6) Pejabat pencatatan sipil pada intansi pelaksana membubuhkan tandatangan secara elektronik kepada pemohon; 7) Petugas mengirimkan pemberitahuan melalui surat elektronik kepada pemohon; 8) Pemohon dapat mencetak kutipan Akta Kelahiran yang telah ditandatangani secara elektronik oleh pejabat pencatatan sipil. Kutipan Akta Kelahiran hanya hanya dapat dicetak 1 (satu) kali, apabila terjadi kesalahan dalam pencetakan Akta kelahiran, pemohon melaporkan kepada intansi pelaksana melalui surat elektronik.

Pelayanan akta kelahiran bertujuan memberikan Perlindungan dan Pengakuan terhadap Penentuan Status Pribadi dan Status Hukum setiap Peristiwa Kependudukan dan Peristiwa Penting yang dialami oleh Penduduk yang berada di dalam dan/atau di
Luar Wilayah Negara Kesatuan Republik Indonesia. Sehubungan dengan hal tersebut Sutopo dan Sugiyanti (1998:62) menyatakan "titik awal dari siklus pengembangan pelayanan adalah pembaharuan disain". Yang dimaksud pembaharuan disain tidak selalu harus menciptakan yang baru sama sekali. Pelayanan yang sudah ada secara berkala juga mernerlukan pembaharuan agar semakin dapat memenuhi kebutuhan pelanggan. Kebutuhan untuk menciptakan pelayanan yang baru sama sekali biasanya terjadi karena perubahan yang mendasar pada tingkat visi dan misi organisasi, sehingga dirasa perlu menyesuaikan tugas pokok dan fungsi unit-unit dalam organisasi bersangkutan.

Pelayanan prima hanya akan berhenti sebagai angan-angan saja, jika diterapkan secara nyata dalam penyelenggaraan sehari-hari pada setiap jenis pelayanan. Aplikasi pelayanan prima bukanlah hal yang mudah, karena membutuhkan tingkat kesungguhan (komitmen), penguasaan, dan konsistensi tindakan yang sangat tinggi. Komitmen untuk sungguh-sungguh menyelenggarakan pelayanan prima tentu bersifat sangat pribadi. Hanya diri kita sendiri yang dapat mengetahui, menilai, mengukur dan membangkitkannya. Namun demikian, hasil penelitian menunjukkan bahwa komitmen selain memang merupakan prasyarat untuk keberhasilan pelayanan prima tetapi sekaligus juga merupakan salah satu hasil utama dari penyelenggaruhi pelayanan yang prima. Setiap kali kita melaksanakan pelayanan, akan diperoleh rasa kepuasan sampai pada kadar tertentu.

Hasil penelitian menunjukkan bahwa upaya mewujudkan pelayanan prima sungguh memerlukan waktu dan perhatian. Karena organisasi kita, dan juga masyarakat yang kita layani selalu tumbuh dan berkembang secara dinamis, maka aplikasi pelayanan prima akan lebih tepat jika kita sikapi sebagai sebuah proses pembelajaran organisasi yang tak berkesudahan. Sebuah pencarian tanpa henti terhadap wujud nyata dari apa yang kita pahami sebagai yang terbaik. Dilihat sebagai proses, aplikasi pelayanan yang baik merupakan upaya perbaikan secara bertahap, dan berkelajutan. Langkah-langkah perbaikannya 
perlu dilakukan dengan mengikuti siklus pengembangan pelayanan. Jika siklus ini diulangulang secara teratur dari waktu ke waktu, maka akan menghasilkan semacam alur spiral dari sejarah perkembangan sebuah pelayanan, menuju Bentuknya yang semakin hari menjadi semakin prima.

Berdasarkan hasil penelitian dengan Penerima layanan Akta Kelahiran tentang prosedur pelayanan Kelahiran di Dinas Kependudukan dan Pencatatan Sipil, diketahui bahwa prosedur pelayanan yang ditetapkan dalam pengurusan Akte Kelahiran tergolong dalam kategori mudah dan tidak berbelitbelit. Meskipun demikian, masih terdapat Penerima layanan Akta Kelahiran yang berpendapat bahwa prosedur pelayanan yang ada di Dinas Kependudukan dan Pencatatan Sipil termasuk dalam kategori tidak mudah dan masih berbelit belit. Adanya Penerima layanan Akta Kelahiran yang menyatakan tidak mudah misalnya dari segi kecepatan prosedur serta persyaratan yang harus dipenuhi mereka menyatakan bahwa prosedur pelayanan yang didapat dari petugas cenderung berbelit belit dan terlalu banyak persyaratan yang harus dipenuhi sehingga menyebabkan pelayanan yang mereka dapatkan harus menempuh waktuyang cukup lama.

Berdasarkan hasil penelitian terlihat bahwa penyelenggaraan administrasi kependudukan yang dilaksanakan selama ini sudah berjalan sesuai harapan, mengingat manajemen pendaftaran, pencatatan dan pengendalian penduduk serta pengelolaan datanya sudah dilakukan secara baik dan tertib, sehingga mengakibatkan pertumbuhan penduduk menjadi terkendali serta pemanfaatan data penduduk bagi kepentingan pembangunan menjadi maksimal.

\section{Kebijakan Peningkatan Kualitas Pelayanan}

Penyelenggaraan pelayanan publik yang berkualitas merupakan kewajiban yang harus dilakukan oleh setiap penyelenggara negara. Bahkan dikatakan bahwa salah satu tolok ukur keberhasilan penyelenggaraan negara dapat dilihat dari kualitas pelayanan publik yang disediakan. Oleh karena itu upaya pemerintah Kabupaten Sintang melalui Dinas Kependudukan dan Pencatatan Sipil untuk menyelenggaraakan pelayanan pembuatan Akta Kelahiran yang berkualitas dan berkeadilan terus menerus dilakukan melalui berbagai kebijakan pengaturan dibidang pelayanan pembuatan Akta Kelahiran. Paradigma pelayanan yang dikembangkan pun bergeser dari yang berorientasi pada pelayanan yang keadilan distributif menuju pada pelayanan yang keadilan yang komotatif, pelayanan dilaksanakan lebih demokratis dan berorientasi pada kepentingan para pihak yaitu penyelenggara pelayanan dan pengguna pelayanan pembuatan Akta Kelahiran.

Kebijakan, dalam hal ini kebijakan yang mengatur pelayanan pembuatan Akta Kelahiran, dikonsepkan sebagai sebuah "konstruksi" yang batasan definitifnya terikat pada dimensi dan waktu takala subjek-subjek berinteraksi secara komunikatif untuk menghasilkan produk pemikiran yang sama. Artinya, keijakan dalam konteks studi pelayanan publik tidak akan difahami sebagai entitas normatif yang objektif semata, tetapi dipahami sebagai dependen variable dari suatu proses sosial politik yang melibatkan sejumlah actor individu yang berpartisipasi dalam suatu proses.

Dengan demikian, proses konstruksinya, dengan demikian, juga tidak dipahami sekadar tehnik konstruksi kebijakan sebagai prosedur standar, tetapi dipahami sebagai totalitas proses yang berada dalam keadaan saling berkait dengan variable sosial, kultur dan politik. Konstruksi kebijakan pelayanan publik dipahami sebagai produk politik yang karakternya antara lain ditentukan oleh dinamika sosial yang berkaitan dengan administrasi publik dan lebih khusus lagi berkenaan dengan kebijakan pelayanan publik.

Oleh karena itu didalam mengkonstruksi kebijakan pelayanan publik salah satunya pelayanan pembuatan Akta Kelahiran, maka konstruksi kebijakan penyelenggaraan pelayanan publik harus lebih memenuhi harapan masyarakat. yang memungkinkan terealisasinya Standar Pelayanan, dalam kerangka penyelenggaraan kebijakan pelayanan pembuatan Akta Kelahiran, 
yang lebih responsif dan partisipatif dan yang secara khusus lebih bersesuai dengan kondisi yang berkembang dalam masyarakat Kabupaten Sintang.

Diketahui lewat penelitian ini bahwa perubahan-perubahan sosial-kultural dan politik telah terjadi di daerah-daerah, yang berdampak pada terjadinya pergeseran yang menuju ke terjadinya berbagai ragam respons, yang dapat diduga akan lebih memenuhi tututan dan kebutuhan masyarakat. Pergeseran ini berseiring dengan pergeseran paradigma yang mengarah ke paradigma baru yang disebut The New Public Service Paradigm, yang mensyaratkan terpenuhinya kriteria partisipasi, keadilan sosial, transparansi, kepastian dan keterjangkauan bagi dan oleh masyarakat yang berhak atas pelayanan publik. Dari penelitian yang dilakukan diwilayah penelitian diperoleh fakta regulasi dan Standar Pelayanan Publik yang bervariasi sehubungan dengan kondisi sosial, budaya dan kebutuhan masyarakat.

Pemberian ruang partisipasi masyarakat dalam pengaturan penyelenggaraan pelayanan pembuatan Akta Kelahiran dimaksudkan untuk mengakomodasi tuntutan demokrasi yang berkembang dalam masyarakat. Dengan diakomodasinya kepentingan dan kebutuhan masyarakat diharapkan akan terbangun komitmen bersama dalam kegiatan penyelenggaraan pelayanan dalam masyarakat. Komitmen bersama dapat dibina dengan mengesampingkan kepentingan dan ego kedinasan dalam masyarakat. Pengaturan penyelenggaraan pelayanan pembuatan Akta Kelahiran yang dibangun dengan komitmen bersama akan menghasilkan kebijakan dan aturan yang mencerminkan moralitas kerjasama. Perilaku penyelenggara pelayanan dan masyarakat pengguna pelayanan akan tunduk pada prinsip-prinsip dan kebijakan yang telah disepakati.

Sementara itu, mekanisme pengaturan dan penyelenggaraan pelayanan pembuatan Akta Kelahiran pun dapat diharapkan kalau akan berjalan dalam suatu situasi saling kontrol antara para penyelenggara dan warga masyarakat pengguna jasa pelayanan. Melalui mekanisme ini akan tercipta pelayanan yang berkeadilan serta meningkatkan posisi warga, tidak saja sebagai pengguna pelayanan saja tetapi juga sebagai pihak yang akan lebih berposisi tawar (bargain) yang lebih baik untuk mendapatkan jasa pelayanan yang lebih baik. Tanggung jawab bersama yang dikembangkan melalui ruang partisipasi masyarakat dengan model tersebut di atas juga dapat diharapkan akan merangsang penyelenggara pelayanan untuk mengembangkan dan memperluas kompetensi aparaturnya agar senantiasa dapat melaksanakan tugas pelayanan dengan lebih baik.

Model penyedian ruang partisipasi masyarakat dalam pengaturan dan penyelenggaraan pelayanan, diharapkan akan mampu memberi pembelajaran kepada masyarakat untuk lebih bertanggungjawab dalam proses demokrasi yang sedang berjalan. Model partisipasi dalam penyelenggaraan pelayanan yang mengedepankan tanggungjawab bersama, para pihak diharapkan senantiasa mengembangkan pencarian alternatif secara positif berkait sistem pengaturan, system penyelenggaraan, dan kewajiban berswasembada untuk tidak bergantung kepada pihak luar. Pemberian insentif kepada penyelenggara dan pengguna pelayanan dapat dikembangkan melalui forum pelibatan para pihak dalam ruang partisipasi masyarakat

Regulasi penyelenggaraan pelayanan publik yang melibatkan para pihak dengan tujuan terbinanya komitmen bersama dalam ruang partisipasi masyarakat, ialah antara penyelenggara pelayanan dan warga masyarakat, akan mengantar para pihak ke dalam proses pengaturan penyelenggaraan pelayanan yang lebih responsif. Sebuah regulasi yang dapat memenuhi tuntutan agar aturan hukum terkonstruksi sebaga produk proses yang lebih responsif pada kebutuhan sosial yang terasa mendesak, dan bersamaan dengan itu juga tetap mempertahankan kontruksi-konstruksi normatif.

Berdasarkan hasil penelitian dan pemikiran teoretisisasinya, menyarankan perlunya mengatur 
pelayanan pembuatan Akta Kelahiran dengan suatu regulasi yang diundangkan dalam bentuk suatu Peraturan Daerah Kabupaten Sintang yang tanggap pada norma-norma lokal yang terpilih sebagaimana yang berlaku dan berkembang dalam masyarakat. Peraturan Daerah yang menetapkan Standar Pelayanan Pembuatan Akta Kelahiran yang tanggap pada tuntutan daerah seperti itu boleh diharapkan akan mampu menyelesaikan berbagai problem praktis yang mengatur prosedur, penetapan biaya, waktu dan mekanisme pengaduan dan penetapan fasilitas pelayanan yang nantinya akan melahirkan kualitas pelayanan.

Standar Pelayanan Pembuatan Akta Kelahiran yang disusun secara konstruktif dan lebih responsif, dengan mengundang partisipasi masyarakat seperti itu, dipandang perlu untuk diproses lebih lanjut, sehingga tidak lagi berwujud penetapan normatif yang sentral, melainkan sudah berupa kontrak pelayanan antara pemerintah daerah dan masyarakat setempat. Standar Pelayanan untuk kepentingan publik seperti itu amat mendesak untuk segera diwacanakan.

\section{KESIMPULAN DAN SARAN}

Tata cara pelayanan pembuatan Akta Kelahiran Di Dinas Kependudukan Dan Pencilatan Sipil Kabupaten Sintang dari aspek kualitas pelayanan, memberikan kemudahan dalam pelayanan Akta Kelahiran serta dari aspek pelayanan pencatatan pelaporan kelahiran dengan prosedur secara manual maupun secara online

\section{DAFTAR PUSTAKA}

Irawan, Hamdi. 2002. 10 Prinsip Kepuasan Pelanggan. Jakarta: PT Gramedia.

Kencana, Syafie, Inu, et. a1. 1999. Ilmu Administrasi Publik. Cetakan Pertama. Jakarta: Rineka Cipta.

Osborne, David. \& Ted Gaebler.1992. Reinventing Government: How the Entrepreneural Spirit Transforming the Public Sector. Jakarta: LPPM. dengan persayaratan yang mudah sesuai dengan Peraturan Menteri Dalam Negeri Nomor 9 Tahun 2016 tentang Percepatan Peningkatan Cakupan Kepemilikan Akta Kelahiran. Didalam merumuskan kebijakan pelayanan pembuatan Akta Kelahiran, maka konstruksi perumusan kebijakan penyelenggaraan pelayanan pembuatan Akta Kelahiran harus lebih memenuhi harapan masyarakat. yang memungkinkan terealisasinya Standar Pelayanan Pembuatan Akta Kelahiran, dalam kerangka penyelenggaraan kebijakan pelayanan kepada masyarakat, yang lebih responsif dan partisipatif dan yang secara khusus lebih bersesuai dengan kondisi yang berkembang dalam masyarakat di Kabupaten Sintang.

Berdasarkan hasil penelitian dan pemikiran teoretisisasinya, penelitian ini menyarankan perlunya mengkonstruksi perumusan kebijakan pelayanan pembuatan Akta Kelahiran dengan suatu regulasi yang tanggap pada norma-norma lokal yang terpilih sebagaimana yang berlaku dan berkembang dalam masyarakat setempat. Model penetapan kebijakan pelayanan pembuatan Akta Kelahiran yang tanggap pada tuntutan daerah seperti itu boleh diharapkan akan mampu menyelesaikan berbagai problem praktis yang mengatur prosedur, penetapan biaya,waktu dan mekanisme pengaduan dan penetapan fasilitas pelayanan. Perlu dilakukan sosialisasi kepada masyarakat secara berkesinambungan tentang tata cara pembuatan Akta Kelahiran, baik mengenai prosedur, biaya, waktu, dan kegunaannya

Warella Y. 1997. Administrasi Negara dan Kualitas Pelayanan Publik. Pidato Pengukuhan sebagai Guru Besar Ilmu Administrasi Negara. Semarang: Fakultas Ilmu Sosial dan Ilmu Politik, Universitas Diponegoro.

,1995. Managemen Pelayanan Publik. Jakarta: Lembaga Administrasi Negara. 